\title{
Penurunan Motilitas dan Daya Fertilitas Sperma Ikan Lele Dumbo (Clarias spp) Pasca Perlakuan Stress Kejutan Listrik
}

\author{
Abdul Rahem Faqih* \\ Fakultas Perikanan dan IImu Kelautan, Universitas Brawijaya, Malang
}

\begin{abstract}
Abstrak
Transgenik pada ikan lele dumbo (Clarias spp) dengan menggunakan metode elektroporasi pada sperma ikan sebagai media transfer gen masih belum pernah dilakukan di Indonesia, sehingga perlu dilakukan percobaan pemberian tegangan pada sperma ikan lele dumbo tersebut. Tujuan dilakukan penelitian ini adalah untuk mengetahui pengaruh stress kejutan listrik (V) terhadap (motilitas) sperma dan daya fertilisasi sperma ikan lele dumbo. Penelitian ini dilaksanakan di Laboratorium Breeding (Budidaya Perairan) Fakultas Perikanan dan IImu Kelautan serta di Laboratorium Sentral IImu Hayati (LSIH) Universitas Brawijaya Malang, Jawa Timur mulai bulan Januari sampai Juni 2009. Rancangan percobaan yang digunakan yaitu Rancangan Acak Lengkap (RAL) dengan 5 perlakuan 3 kali ulangan dan 1 kontrol. Sebagai perlakuan adalah perbedaan pemberian stress kejutan listrik dengan Gene pulser pada tegangan: A (40 V), B (160 V), C (280 V), D (400 V), E (520 V. Hasil penelitian menunjukkan bahwa pemberian stress kejutan listrik dengan tingkat voltase yang berbeda berpengaruh nyata terhadap motilitas sperma namun tidak berpengaruh nyata terhadap daya fertilisasi dan viabilitas sperma serta daya tetas telur. Berdasarkan analisis polynomial orthogonal didapatkan hubungan antara perlakuan tegangan dengan hasil motilitas sperma berbentuk linier dengan persamaan $y=39,198-0,04 x$ dengan $R^{2}=0,933$ dan $r=0,966$. Semakin tinggi tegangan yang diberikan maka semakin rendah motilitas sperma yang dihasilkan. Dari hasil penelitian ini dapat disarankan bahwa elektroporasi pada sperma ikan lele dumbo (Clarias spp) sebagai media transfer gen sebaiknya dilakukan pada tegangan $40 \mathrm{Vcm}^{-1}$ dengan satu kali kejutan dan lama kejutan 0,05 ms.
\end{abstract}

Kata kunci: Clarias spp, sperma, elektroporasi, tegangan, transgenik

\section{PENDAHULUAN}

Sperma memiliki kelebihan dalam bertindak sebagai media transfer gen, karena sperma menggunakan vektor alami dalam mentransfer gen [1]. Sel sperma telah digunakan sebagai vektor transfer gen pada ikan [2]. Masuknya konstruksi gen ke dalam sperma dapat dipermudah dengan penggunaan elektroporator dan efektifitas transfer gen dengan elektroporasi sperma sangat dipengaruhi kondisi listrik dan parameter biologi [3].

Metode elektroporasi menggunakan serangkaian listrik arus pendek untuk melemahkan membran sel untuk membantu transgen atau DNA rekombinan masuk dalam sel tertentu [4]. Menurut Taghyr (2008), tegangan listrik adalah perbedaan potensi listrik antara dua titik dalam rangkaian listrik, dinyatakan dalam

\footnotetext{
* Alamat korespondensi penulis:

Abdul Rahem Faqih

Email : faq_ub@yahoo.com

Alamat : Fakultas Perikanan dan Ilmu Kelautan,

Universitas Brawijaya, Jl. Veteran, Malang
}

satuan volt. Besaran ini mengukur energi potensial sebuah medan listrik untuk menyebabkan aliran listrik dalam sebuah konduktor listrik [5].

Integrasi DNA kedalam sperma tergantung pada tegangan listrik $\left(\mathrm{kVcm}^{-1}\right.$ atau $\left.\mathrm{Vcm}^{-1}\right)$, jumlah kejutan yang dikenakan dan konsentrasi DNA. Sedangkan efisiensi transfer DNA, dengan media sperma yang dielektroporasi sangat dipengaruhi oleh tegangan dan lama kejutan [6]. Elektroporasi memfasilitasi terbentuknya poripori temporal pada permukaan membran sel target [7]. Metode elektroporasi adalah suatu metode yang berhasil dalam transfer gen pada sel jaringan yang dikultur dan metode ini pada tahun 1990 dianggap metode terbesar yang berhasil dalam transgenik ikan [8].

Transgenik pada ikan lele dumbo (Clarias spp) dengan menggunakan metode elektroporasi pada sperma ikan sebagai media transfer gen masih belum pernah dilakukan di Indonesia, sehingga perlu dilakukan percobaan pemberian tegangan yang berbeda untuk mendapatkan tegangan yang optimal karena menurut Symond 
et al., (1994), efisiensi transfer DNA dengan media sperma yang dielektroporasi sangat dipengaruhi oleh tegangan dan lama kejutan [6]. Selain itu ditambahkan oleh Weaver (1995), apabila tegangan yang diberikan terhadap sperma terlalu berlebihan maka dapat menyebabkan pembukaan pori-pori yang terlalu lebar dan gagal untuk menutup seperti semula, sehingga dapat mengakibatkan sel rusak atau pecah, oleh sebab itu maka perlu diketahui tegangan yang sesuai sehingga tidak sampai terjadi kerusakan pada sel sperma [9].

Tujuan penelitian ini adalah untuk mengetahui pengaruh stress kejutan listrik dengan gene pulser pada tegangan berbeda (V) terhadap pergerakan (motilitas) sperma dan daya fertilisasi sperma ikan lele dumbo dalam membuahi telur.

\section{METODE PENELITIAN}

Rancangan percobaan yang digunakan dalam penelitian ini adalah Rancangan Acak Lengkap. Penelitian ini menggunakan 5 perlakuan dan kontrol yang masing-masing diulang sebanyak 3 kali. Dalam penelitian ini, perlakuan yang diberikan adalah sebagai berikut:

Perlakuan $A$ = pemberian kejutan listrik dengan tegangan 40 volt

Perlakuan $\mathrm{B}=$ pemberian kejutan listrik dengan tegangan 160 volt

Perlakuan $\mathrm{C}=$ pemberian kejutan listrik dengan tegangan 280 volt

Perlakuan $D=$ pemberian kejutan listrik dengan tegangan 400 volt

Perlakuan $E=$ pemberian kejutan listrik dengan tegangan 520 volt

Perlakuan $\mathrm{K}=$ tanpa pemberian kejutan listrik

Prosedur Penelitian

Persiapan Penelitian

Menyiapkan induk jantan ikan lele dumbo yang sudah matang gonad untuk diambil spermanya dengan cara membedah tubuhnya. Kemudian menyiapkan alat elektroporasi.

Pengambilan Sperma

Induk jantan ikan lele dumbo yang sudah matang gonad diukur panjangnya dan ditimbang beratnya, kemudian kepalanya dipotong dan dibedah untuk diambil gonadnya. Setelah itu gonad ditimbang dan sperma dikeluarkan dengan cara memeras gonad, sperma ditampung dalam botol film.

\section{Pengamatan Sperma Pra Elektroporasi}

Sperma dalam botol film diambil menggunakan mikropipet kemudian dimasukkan dalam gelas ukur $10 \mathrm{ml}$. Setelah itu dilakukan penghitungan jumlah sel sperma menggunakan dan juga diamati motilitas dan viabilitas sperma.

\section{Proses Elektroporasi}

Sperma dimasukkan sebanyak $25 \mu$ l kedalam cuvette setelah itu tutup rapat. Kemudian masukkan cuvette dalam shock pod, setelah itu pilih tegangan yang akan diberikan dan tekan tombol "pulse" untuk memberikan tegangan. Perlakuan pada tiap tegangan diulang sebanyak tiga kali.

\section{Pengamatan Sperma Pasca Elektroporasi}

Setelah sperma diberi kejutan kemudian ditambahkan larutan Natrium Fisiologis pada sperma dalam cuvette. Setelah itu sperma dituang kedalam mikrotube dan diambil untuk pengamatan motilitas dan viabilitas sperma masing-masing $5 \mu \mathrm{l}$. Sperma yang tersisa digunakan untuk membuahi telur yang sudah disiapkan sebanyak \pm 271 butir. Setelah itu diamati daya fertilisasi sperma dan juga telur diamati hingga menetas untuk mengetahui HR.

\section{Parameter Uji Penelitian}

\section{Motilitas Spermatozoa}

Motilitas spermatozoa adalah parameter yang berguna untuk memperkirakan kelangsungan hidup spermatozoa. Sperma yang hidup adalah sperma yang bergerak cepat, lambat atau pergerakannya pada kepala atau ekor, sedangkan sperma yang mati adalah sperma yang tidak memperlihatkan pergerakan sama sekali baik kepala maupun ekor.

Lama motilitas dan daya fertilisasi sperma tiap jenis ikan berbeda-beda, tetapi pada umumnya motilitas dan kemampuan sperma untuk membuahi telur adalah sejalan. Menurut Sucipto (2008), spermatozoa akan bergerak (motil) menuju mikrofil (lubang berukuran mikro pada sel telur) [11].

\section{Fertilitas (Pembuahan)}

Fertilitas adalah kemampuan sperma ikan untuk mampu membuahi telur. Pada proses fertilisasi terjadi penggabungan inti spermatozoa dengan inti telur dalam sitoplasma sehingga membentuk zigot. Fertilitas merupakan persentase keberhasilan proses penyatuan sel gamet jantan dan sel gamet betina untuk membentuk satu sel (zygot) [12]. Telur yang terbuahi dan yang tidak terbuahi dihitung kemudian dilanjutkan dengan menghitung persentase fertilitas dengan rumus sebagai berikut [12]:

\section{Fertilitas $=\underline{\Sigma \text { telur yang terbuahi } \times 100 \%}$} $\Sigma$ Total telur 


\section{Viabilitas Spermatozoa}

Viabilitas spermatozoa adalah parameter yang diukur untuk mengetahui kelangsungan hidup spermatozoa setelah diberi perlakuan dengan tegangan yang berbeda. Setelah sperma diberi kejutan listrik kemudian diwarnai menggunakan eosin-negrosin dan selanjutnya diamati menggunakan mikroskop dengan perbesaran 400x.

\section{Viabilitas $=\underline{\Sigma \text { sel sperma hidup } \times 100 \%}$ 200}

\section{Hatching Rate (HR)}

Hatching Rate (daya tetas) menunjukkan persentase telur dari awal fertilisasi hingga telur yang menetas. Daya tetas telur merupakan prosentase telur yang menetas dibandingkan dengan telur awal. Menurut Sin (2001), kondisi saat proses elektroporasi juga dapat mempengaruhi daya tetas telur. Daya tetas telur dapat dihitung dengan menggunakan rumus sebagai berikut [13]:

\section{$H R=\underline{\Sigma \text { telur yang menetas } \times 100 \%}$ $\Sigma$ telur awal fertilisasi}

\section{Kualitas Air}

Pengamatan inkubasi telur yang dibuahi oleh sperma perlu dilakukan pengamatan kualitas air, pengukuran kualitas air meliputi pengukuran suhu, (DO) oksigen terlarut dan derajat keasaman ( $\mathrm{pH})$. Pengukuran suhu dilakukan dengan menggunakan termometer, pengukuran oksigen terlarut dilakukan dengan menggunakan oxymeter dan pengukuran derajat keasaman dilakukan dengan menggunakan $\mathrm{pH}$ meter.

\section{Analisa Data}

Data yang diperoleh dari penelitian ini dianalisa secara statistik dengan menggunakan analisa keragaman (ANOVA), sesuai dengan rancangan yang digunakan yaitu Rancangan Acak Lengkap (RAL). Jika dari data sidik ragam diketahui bahwa perlakuan menunjukkan pengaruh beda nyata (significant) atau berbeda sangat nyata (highly significant), maka untuk membandingkan nilai antar perlakuan dilanjutkan dengan uji BNT (Beda Nyata Terkecil0 dan analisa regresi.

\section{HASIL DAN PEMBAHASAN \\ Kualitas Spermatozoa Ikan Lele}

Kondisi sperma ikan lele yang digunakan pada saat penelitian mempunyai kualitas yang cukup baik, sperma yang diambil dari indukan dengan berat rata-rata $1,15 \mathrm{~kg}$ dan didapatkan volume sperma rata-rata yaitu $1,5 \mathrm{ml}$ dengan berat gonad rata-rata $6,6 \mathrm{gr}$, ciri-ciri fisik sperma yaitu berwarna putih susu dan cukup kental. Menurut Harvey dan Hoar (1979), beberapa karakteristik semen ikan antara lain berwarna putih susu dan berbau khas, produksi spermatozoa setiap gram berat badan, 4000 juta dan motilitas spermatozoa 10 menit di air tawar [14].

Dari hasil perhitungan jumlah kepadatan sel sperma ikan lele didapatkan sekitar 5,6 $\times 10^{9}$ selml $^{-1}$ menurut Dacie dan Lewis (1984) dan Rustidja (2000), konsentrasi sperma ikan berkisar $\pm 3,7-11,9 \times 10^{9}$ spermatozoa $\mathrm{ml}^{-1}$ cairan, karena untuk ikan yang mampu menghasilkan telur sampai ratusan ribu butir selain konsentrasinya yang tinggi, maka akan membutuhkan volume sperma yang lebih banyak pula $[15,16]$. Kualitas sperma dapat dilihat dari dua parameter yaitu motilitas dan viabilitas sperma.

\section{Motilitas Sperma Kontrol}

Sebelum sperma diberikan perlakuan, maka perlu diketahui motilitas sperma kontrol. Dari hasil pengamatan diketahui rata-rata motilitas sperma kontrol sebesar $60 \%$ (Tabel 1), hal ini sudah menunjukkan sperma tersebut dalam kondisi yang cukup bagus karena menurut Toelihere (1981), persentase motilitas spermatozoa yang dikatakan kurang baik dalam proses pembuahan telur apabila di bawah $40 \%$, karena sering menyebabkan pembuahan tidak berhasil [17].

Tabel 1. Motilitas Sperma kontrol (\%)

\begin{tabular}{cccccc}
\hline \multirow{2}{*}{ Perlakuan } & \multicolumn{3}{c}{ Ulangan } & \multirow{2}{*}{ Total } & \multirow{2}{*}{ Rata-rata } \\
\cline { 2 - 4 } & 1 & 2 & 3 & & \\
\hline Kontrol & 60 & 60 & 60 & 180 & 60.00 \\
\hline
\end{tabular}

Kualitas sperma dengan tingkat motilitas $60 \%$ dapat dikatakan bagus karena menurut Tabares (2007), pada penelitiannya menggunakan ikan Brycon henni (ikan air tawar) menunjukkan bahwa pada sperma kontrol memiliki tingkat motilitas $78 \%$ karena dalam cairan seminal plasmanya terdapat ion yang lengkap seperti $\mathrm{KCl}$, $\mathrm{NaCl}, \mathrm{CaCl}_{2}$ dan $\mathrm{MgCl}_{2}$. Fungsi cairan seminal antara lain mengembangkan kapasitas sperma dalam bergerak [19]. Selain itu, fungsi cairan seminal juga mempertahankan motilitas sperma saat bergerak dalam air [20].

\section{Viabilitas Sperma Kontrol}

Dari hasil pengamatan preparat sperma yang sudah diwarnai dengan eosin-negrosin, diketahui viabilitas sperma yaitu sekitar $85 \%$ (Tabel 2). Seperti diketahui bahwa persentase viabilitas sperma menentukan kualitas sperma tersebut karena hal itu menunjukkan bahwa jumlah 
spermatozoa yang hidup cukup tinggi sehingga dapat meningkatkan keberhasilan proses pembuahan. Persentase hidup sel spermatozoa dalam sperma yang baik minimal $70 \%$. Semakin besar jumlah viabilitas sperma, maka kemampuan spermatozoa untuk menembus lubang mikropil pada sel telur juga semakin tinggi [24].

Tabel 2. Viabilitas Sperma Kontrol (\%)

\begin{tabular}{cccccc}
\hline \multirow{2}{*}{ Perlakuan } & \multicolumn{3}{c}{ Ulangan } & Total & $\begin{array}{c}\text { Rata- } \\
\text { rata }\end{array}$ \\
\cline { 2 - 4 } & 1 & 2 & 3 & & 255 \\
\hline Kontrol & 99 & 81,5 & 74,5 & 255 \\
\hline
\end{tabular}

\section{Kualitas Spermatozoa Pasca Elektroporasi}

Setelah sperma diberi kejutan listrik dilakukan penambahan larutan Natrium fisiologis sebanyak $375 \mu \mathrm{l}$, yang bertujuan untuk mempermudah pengambilan sperma karena sedikitnya jumlah sperma $(25 \mu \mathrm{l})$ yang dimasukkan ke dalam cuvet ( $2 \mathrm{~mm}$ ). Selain itu penambahan pengencer juga diharapkan akan membantu mempertahankan kondisi sperma [21].

Pengamatan motilitas dan viabilitas dilakukan dengan mengambil larutan sperma yang sudah ditambahkan Natrium fisiologis masing-masing $5 \mu \mathrm{l}\left(7 \times 10^{5}\right.$ sel sperma $\left.\mu l^{-1}\right)$. Untuk mengamati motilitas sperma, sperma yang sudah diambil diteteskan pada object glass dan diletakkan di bawah mikroskop dengan perbesaran 400x, setelah didapatkan fokus kemudian diteteskan air pada preparat sperma dan ditutup dengan cover glass, setelah itu seketika diamati oleh minimal 3 orang agar mendapatkan nilai ratarata motilitas. Sedangkan untuk mengetahui viabilitas sperma, $5 \mu \mathrm{l}$ sperma yang sudah diambil diteteskan pada object glass kemudian diwarnai dengan pewarna eosin-negrosin, setelah preparat kering kemudian diamati di bawah mikroskop dan dihitung sel sperma yang hidup dan mati sejumlah 200.

\section{Motilitas Spermatozoa}

Dari hasil penelitian diketahui pengaruh pemberian tegangan $A(40 \mathrm{~V}), \quad B(160 \mathrm{~V}), C(280$ V), $D(400 \mathrm{~V})$ dan $E(520 \mathrm{~V})$ telah menunjukkan hasil yang berbeda terhadap motilitas sperma. Persentase motilitas sperma setelah diberi tegangan dapat dilihat pada Tabel 3.

Dari data pada Tabel 3 dapat diketahui bahwa rerata persentase motilitas yang dihasilkan dari beberapa perlakuan yaitu A $(40 \%)$, B $(30 \%)$, C $(28,33 \%)$, D $(23,33 \%)$ dan E $(18,33 \%)$, jika dibandingkan dengan motilitas sperma kontrol (60\%) maka terlihat terjadi penurunan seperti ditunjukkan pada Gambar 1.
Tabel 3. Pengaruh Pemberian Tegangan Terhadap Motilitas Sperma Ikan Lele (\%)

\begin{tabular}{llllll}
\hline Perlakuan & \multicolumn{3}{l}{ Ulangan } & Total & Rata-rata \\
\cline { 2 - 4 } & 1 & 2 & 3 & & \\
\hline $40 \mathrm{~V}$ & 40 & 30 & 50 & 120 & 40.00 \\
$160 \mathrm{~V}$ & 30 & 30 & 30 & 90 & 30.00 \\
$280 \mathrm{~V}$ & 30 & 25 & 30 & 85 & 28.33 \\
$400 \mathrm{~V}$ & 30 & 30 & 10 & 70 & 23.33 \\
$520 \mathrm{~V}$ & 20 & 20 & 15 & 55 & 18.33 \\
Total & & & & 420 & \\
Kontrol & 60 & 60 & 60 & 180 & 60.00 \\
\hline
\end{tabular}

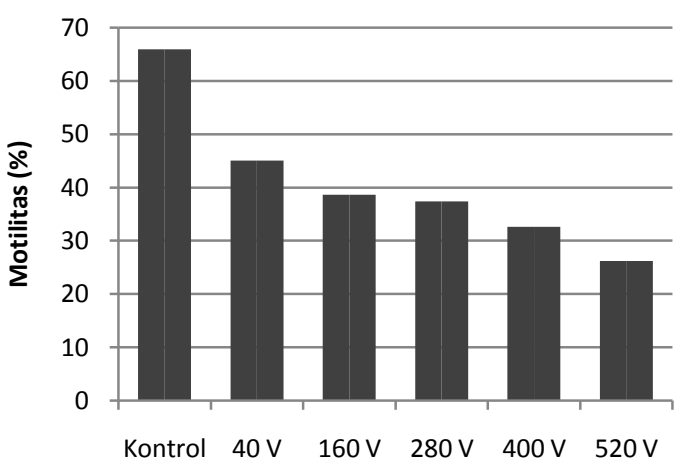

Perlakuan

Gambar 1. Diagram Motilitas Sperma

Pada Gambar 1 menunjukkan bahwa motilitas sperma semakin menurun hal ini menunjukkan bahwa pemberian kejutan listrik pada sperma menyebabkan adanya pembukaan pori-pori yang bersifat sementara namun dikatakan oleh Weaver (1995), apabila tegangan yang diberikan terhadap sperma terlalu berlebihan maka dapat menyebabkan pembukaan pori-pori yang terlalu lebar dan gagal untuk menutup seperti semula, sehingga dapat mengakibatkan sel rusak atau pecah dan hal ini memicu kerusakan pada membran atau selaput sperma [9]. Permeabilitas membran spermatozoa erat kaitannya dengan motilitas spermatozoa karena seperti diketahui permeabilitas membran sangat berkaitan dengan transportasi nutrisi yang penting peranannya dalam metabolisme sel. Sel sperma cenderung akan mengecil setelah dilakukan elektroporasi dan hal ini memungkinkan menurunnya persentase motilitas sperma [3].

Berdasarkan hasil sidik ragam pada Tabel 4 didapatkan hasil yang berbeda nyata. Hal ini menunjukkan bahwa perbedaan tegangan memberikan pengaruh terhadap persentase motilitas sperma ikan lele, yang berarti menerima $\mathrm{H} 1$ dan menolak HO. Selanjutnya dilakukan uji BNT didapatkan hasil seperti pada Tabel 5. 
Tabel 4. Hasil Sidik Ragam Persentase Ragam Motilitas Sperma

\begin{tabular}{lllllll}
\hline $\begin{array}{l}\text { Sumber } \\
\text { ragam }\end{array}$ & $\mathrm{db}$ & $\mathrm{JK}$ & $\mathrm{KT}$ & $\mathrm{F} \mathrm{Hit}$ & $\mathrm{F} \mathrm{5 \%}$ & $\mathrm{F} \mathrm{1 \%}$ \\
\hline Perlakuan & 4 & 790 & 197,5 & $3,95 *$ & 3,48 & 5,99 \\
Acak & 10 & $\begin{array}{l}500 \\
1290\end{array}$ & 50 & & & \\
Total & 14 & 1290 & & & \\
\hline Keterangan : * = F 5\% < F Hitung > F 1 \% & &
\end{tabular}

Tabel 5. Uji Beda Nyata Terkecil

\begin{tabular}{ccc}
\hline Rerata Perlakuan & Rata-rata & Notasi \\
\hline E & 18,33 & a \\
D & 23,33 & a \\
C & 28,33 & ab \\
B & 30 & ab \\
A & 40 & b \\
\hline
\end{tabular}

Keterangan: notasi sama berarti tidak berbeda

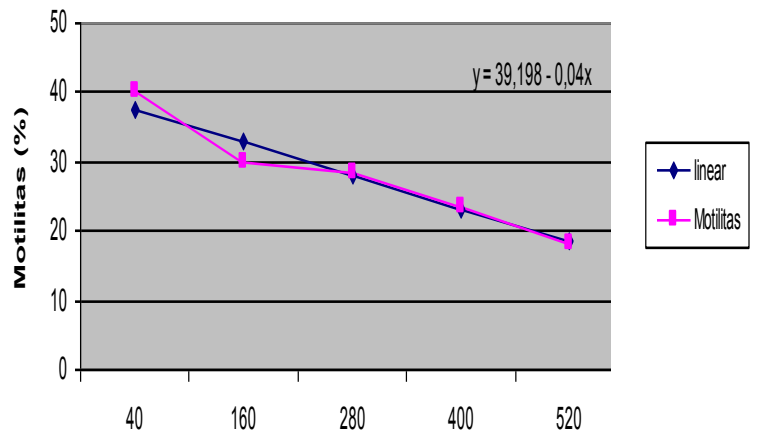

Tegangan $(\mathrm{V} / \mathrm{cm})$

Gambar 2. Grafik hubungan perbedaan tegangan dengan motilitas sperma

Hasil Uji Beda Nyata Terkecil (BNT) menunjukkan bahwa perlakuan A $(40 \mathrm{~V})$ memberikan hasil motilitas terbaik diikuti oleh perlakuan $\mathrm{C}(280 \mathrm{~V})$ dan $\mathrm{B}(160 \mathrm{~V})$ dan yang terakhir adalah perlakuan $\mathrm{D}(400 \mathrm{~V})$ dan $\mathrm{E}(520 \mathrm{~V})$. Perlakuan A memiliki jumlah motilitas tertinggi karena sel sperma masih dalam kondisi yang optimal dibandingkan tegangan yang lebih tinggi yaitu perlakuan B, C, D, E dengan nilai motilitas sperma yang semakin menurun, sesuai pendapat Sun et al (2004), pada tegangan $40 \mathrm{Vcm}^{-1}$ menghasilkan daya tetas dan kelulushidupan udang tertinggi, hal ini menunjukkan bahwa tegangan tersebut menimbulkan kerusakan yang minim pada sel [22].
Selanjutnya berdasarkan uji polinomial orthogonal didapatkan persamaan linear $\mathrm{y}=$ 39,198 - 0,04x dengan koefisien korelasi ( $r$ ) sebesar 0,968 yang berarti bahwa hubungan antara perbedaan tegangan dengan motilitas mempunyai kaitan sangat erat atau hasil motilitas sesuai dengan perlakuan yang diberikan seperti terlihat pada Gambar 2.

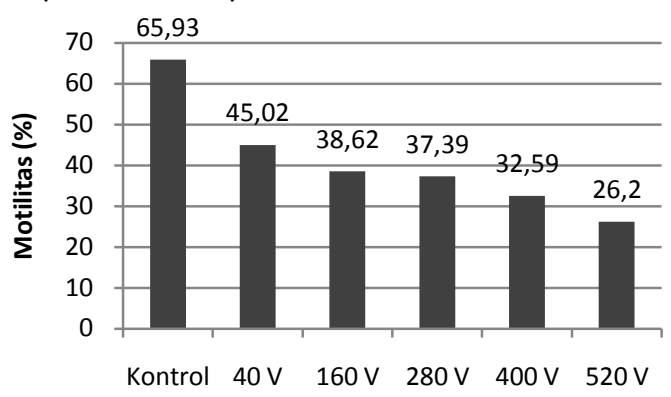

Perlakuan

Gambar 3. Diagram Lama motilitas sperma kontrol dan setelah diberi tegangan.

Seperti yang digambarkan pada Gambar 3., bahwa pemberian perlakuan tegangan menimbulkan penurunan waktu motilitas sperma dengan semakin besarnya tegangan, jika dibandingkan dengan sperma kontrol. Hal ini menunjukkan bahwa sel sperma yang sudah diberi kejutan listrik mengalami pembukaan poripori secara sementara dan terjadi difusi molekul asing ke dalam sel [13]. Berdasarkan pendapat tersebut memungkinkan terjadinya pertukaran cairan makanan untuk metabolisme spermatozoa dengan cairan di luar sel sehingga hal ini menyebabkan waktu motilitas menurun. Hal ini karena pergerakan spermatozoa memerlukan energi [21].

Penurunan waktu motilitas tidak terlihat signifikan karena dilakukan penambahan $\mathrm{Na}$ fisiologis. Menurut Soehartojo (1995) dalam Hidayaturrahmah (2007), pemberian larutan fruktosa sebagai pengencer untuk spermatozoa ikan dimaksudkan untuk memberikan energi dan nutrisi untuk spermatozoa ikan agar dengan energi yang berupa ATP tersebut dapat meningkatkan atau memperpanjang waktu motilitas spermatozoa [21].

Tabel 6. Pengaruh Pemberian Tegangan Terhadap Viabilitas Sperma Ikan Lele (\%)

\begin{tabular}{lcccccc}
\hline Sumber Keragaman & $\mathrm{db}$ & $\mathrm{JK}$ & $\mathrm{KT}$ & $\mathrm{F} \mathrm{Hit}$ & $\mathrm{F} \mathrm{5 \%}$ & $\mathrm{F} \mathrm{1 \%}$ \\
\hline Perlakuan & 4 & 332,58 & 83,14 & $3,23^{\mathrm{ns}}$ & 3,48 & 5,99 \\
Acak & 10 & 257,17 & 25,7 & & \\
Total & 14 & 589,75 & & & \\
\hline
\end{tabular}




\section{Viabilitas Spermatozoa}

Dari data pada Tabel 6 dapat diketahui bahwa rerata persentase viabilitas yang dihasilkan dari beberapa perlakuan yaitu A (80\%), B (78,5\%), C $(73,67 \%), \quad D(70,5 \%)$ dan $E(67,5 \%)$, jika dibandingkan dengan viabilitas sperma kontrol (85\%) maka terlihat terjadi penurunan.

Penurunan viabilitas pada kebanyakan perlakuan terjadi karena tegangan yang diberikan terhadap sperma dapat menyebabkan pembukaan pori-pori yang terlalu lebar dan gagal untuk menutup seperti semula, sehingga dapat mengakibatkan sel rusak atau pecah dan hal ini memicu kerusakan pada membran atau selaput sperma [9]. Permeabilitas membran spermatozoa erat kaitannya dengan viabilitas spermatozoa karena seperti diketahui permeabilitas membran sangat berkaitan dengan transportasi nutrisi yang penting peranannya dalam metabolisme sel. Ditambahkan oleh Jones dan Stewart (1979) dalam Rustidja, (2000) bahwa perubahan infrastruktur pada membran plasma, hilangnya beberapa matrik mitokondria dan penurunan densitas elektron dari matrik mitokondria menyebabkan hilangnya viabilitas spermatozoa [16].

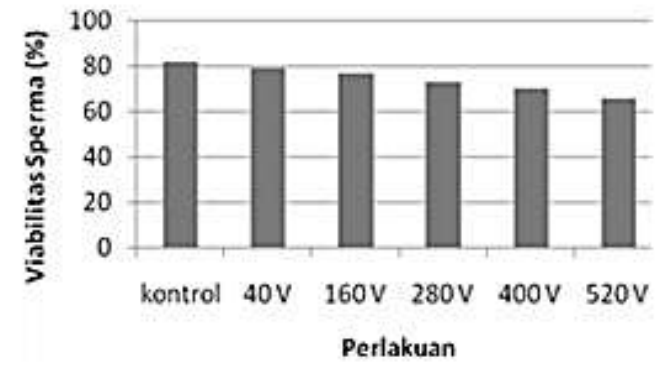

Gambar 4. Diagram Pengaruh Perberian Tegangan Terhadap Viabilitas Sperma Ikan Lele Dumbo

Pada perlakuan dengan tegangan $400 \mathrm{~V}$ dan $520 \mathrm{~V}$ memiliki nilai viabilitas lebih rendah. Hal ini disebabkan karena terjadi peningkatan suhu pada sperma ketika diberi tegangan, hal ini dimungkinkan karena sperma tercampur dengan $\mathrm{Na}$ fisiologis (terdapat kandungan ion) saat pengambilan dengan mikropipet atau juga karena pada saat proses pendinginan cuvette dengan es kurang maksimal. Resistance sampel dapat ditingkatkan dengan cara mengurangi tempratur sampel, mengurangi kadar ion pada pengencer, mengurangi volume cairan dalam cuvette pada kasus media dengan resistance rendah [23]. Sehingga jika sperma (sample) banyak mengandung ion maka resistance dari sampel meningkat sehingga waktu pemberian tegangan semakin lama (pulse length) sehingga suhunya akan meningkat dan menyebabkan sperma mati. Hal ini menurut Toelihere (1981) dalam Rustidja (2000) kemampuan hidup (viabilitas) spermatozoa sangat dipengaruhi oleh suhu dan secara umum akan hidup lebih lama dalam suhu rendah [16].

Selanjutnya dilakukan perhitungan sidik ragam dan didapatkan hasil sidik ragam seperti pada Tabel 7.

Tabel 7. Hasil Sidik Ragam Viabilitas Sperma

\begin{tabular}{cccccc}
\hline \multirow{2}{*}{ Perlakuan } & \multicolumn{3}{c}{ Ulangan } & \multirow{2}{*}{ Total } & $\begin{array}{c}\text { Rata- } \\
\text { rata }\end{array}$ \\
\cline { 2 - 4 } & 1 & 2 & 3 & & 80 \\
$160 \mathrm{~V}$ & 78 & 87,5 & 74,5 & 240 & 80 \\
$280 \mathrm{~V}$ & 72,5 & 73,5 & 80,5 & 235,5 & 78,50 \\
$400 \mathrm{~V}$ & 67 & 75 & 68,5 & 211,5 & 70,50 \\
$520 \mathrm{~V}$ & 70,5 & 75 & 75,5 & 202,5 & 67,50 \\
& Total & & & 1110,5 & 73,67 \\
Kontrol & 99 & 81,5 & 74,5 & 255 & 85 \\
\hline
\end{tabular}

Keterangan: ${ }^{\text {ns }}$ tidak berbeda nyata

Pada Gambar 4 menunjukkan terjadinya penurunan persentase viabilitas sperma pada tiap perlakuan, namun dari hasil perhitungan sidik ragam (Tabel 7) diketahui bahwa perbedaan tegangan tidak berpengaruh terhadap viabilitas sperma ikan lele dumbo, yang berarti menerima $\mathrm{HO}$ dan menolak $\mathrm{H} 1$. Hal ini terjadi dimungkinkan karena metode kejutan yang dipakai yaitu metode square wave karena menurut Chen et al., (2009) bahwa metode ini menghantarkan tegangan tinggi dalam gelombang yang pendek sehingga menimbulkan sedikit panas, sehingga transfer DNA dapat terjadi tanpa membunuh sel atau embrio [24].

\section{Daya Fertilitasi Sperma}

Setelah sperma diberi tegangan kemudian sperma tersebut digunakan untuk membuahi telur dengan jumlah 0,5 g ( \pm 271 butir) dan untuk lebih jelasnya daya fertilisasi sperma dapat dilihat pada Tabel 8 dan Gambar 5.

Dari data Tabel 8 dan Gambar 5 diketahui bahwa rata-rata persentase daya fertilitasi sperma yang telah diberi tegangan, jika dibandingkan dengan rata-rata daya fertilisasi sperma kontrol terlihat terjadi penurunan. Hal ini berhubungan dengan tingkat motilitas sperma yang menunjukkan adanya penurunan dengan semakin besarnya tegangan yang diberikan. Ciereszko et al., (2001) mengungkapkan bahwa keberhasilan suatu pembuahan telur oleh sperma sangat dipengaruhi oleh motilitas sperma [25]. Keadaan viabilitas yang panjang belum 
tentu dapat menghasilkan fertilisasi yang tinggi, karena pada keadaan ini spermatozoa sangat membutuhkan banyak energi untuk membuahi sel telur [21].

Tabel 8. Daya Fertilisasi Sperma Ikan Lele Dumbo Setelah Diberi Tegangan (\%)

\begin{tabular}{|c|c|c|c|c|c|}
\hline \multirow{2}{*}{ Perlakuan } & \multicolumn{3}{|c|}{ Ulangan (\%) } & \multirow{2}{*}{$\begin{array}{c}\text { Total } \\
(\%)\end{array}$} & \multirow{2}{*}{$\begin{array}{c}\text { Rata- } \\
\text { rata } \\
(\%)\end{array}$} \\
\hline & 1 & 2 & 3 & & \\
\hline $40 \mathrm{~V}$ & 47,23 & 52,77 & 35,05 & 135,05 & 45,02 \\
\hline $160 \mathrm{~V}$ & 37,27 & 43,54 & 35,05 & 115,86 & 38,62 \\
\hline $280 \mathrm{~V}$ & 38,01 & 16,97 & 57,19 & 112,17 & 37,39 \\
\hline $400 \mathrm{~V}$ & 26,57 & 39,85 & 31,36 & 97,78 & 32,59 \\
\hline $520 \mathrm{~V}$ & 26,20 & 26,57 & 25,83 & 78,60 & 26,20 \\
\hline Total & & & & 539,46 & \\
\hline Kontrol & 71,58 & 65,68 & 60,52 & 197,78 & 65,93 \\
\hline
\end{tabular}

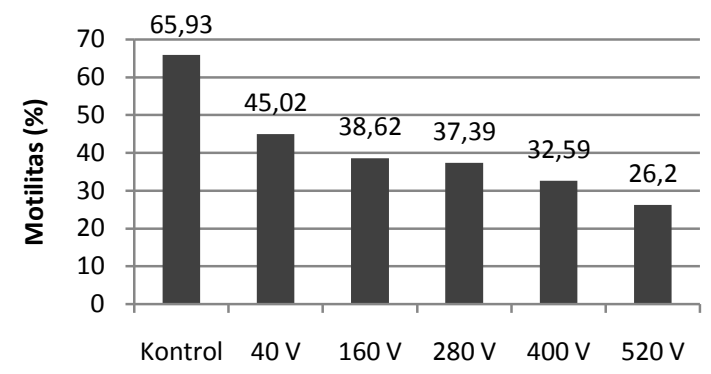

Perlakuan

Gambar 5. Diagram Pengaruh Pemberian Tegangan Terhadap Daya Fertilitasi Sperma.

Hasil sidik ragam (Tabel 9) menunjukkan bahwa pemberian perbedaan tegangan tidak memberikan pengaruh yang nyata terhadap daya fertilisasi sperma, yang berarti menerima $\mathrm{HO}$ dan menolak $\mathrm{H} 1$.

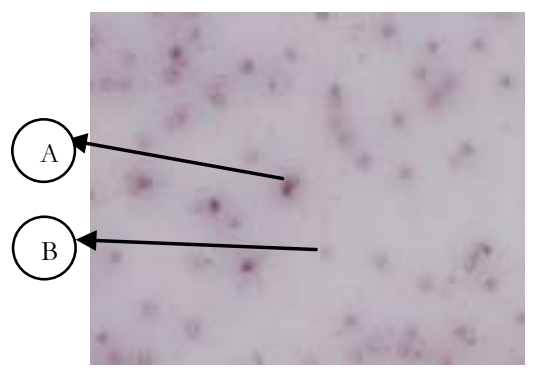

Gambar 6. Gambar Sperma setelah diberi tegangan $280 \mathrm{~V} / \mathrm{cm}$. Keterangan (A) sperma yang mati, (B) sperma yang masih hidup
Menurut Sin (2001), motilitas sperma ikan merupakan parameter kelangsungan hidup sperma, yang akan menurun dengan semakin meningkatnya tegangan dan lama kejutan [13]. Namun kelulushidupan dari embrio yang dibuahi dengan sperma yang dielektroporasi dan dengan sperma tanpa perlakuan tidak tampak perbedaan, dan pada penelitian ini volume sperma yang diberi perlakuan yaitu $25 \mu$ dengan jumlah sel sperma $\pm 5,6$ juta sel tiap $\mu \mathrm{l}$ digunakan untuk membuahi 0,5 gr telur dengan jumlah sel telur \pm 271 butir.

Hal ini menunjukkan bahwa meskipun motilitas sperma yang cenderung menurun tetapi masih tetap bisa membuahi telur dengan ditunjang jarak pembuahan antara sperma dan telur yang dekat (pemijahan buatan) seperti dikatakan oleh Hidayaturrahmah (2007), kondisi motilitas sperma slow progressive mempunyai kemampuan spermatozoa untuk menembus lubang mikropil cukup lemah, pembuahan bisa saja terjadi apabila jarak antara spermatozoa dan sel telur sangat dekat. Sperma pada kondisi viabil, kemampuan spermatozoa untuk melakukan fertilisasi sangat kecil yaitu hanya sekitar $10 \%$. Kondisi spermatozoa yang bergerak perlahan atau berdenyut di tempat dalam mempertahankan viabilitasnya membutuhkan kecepatan dan energi yang besar untuk masuk ke saluran lubang mikropil sel telur [21].

Secara umum sperma yang sudah dielektroporasi masih mampu untuk membuahi karena menurut Sin et al., (1995) setelah diamati dengan mikroskop elektron, sperma yang diberi kejutan listrik tidak nampak adanya kerusakan namun sel sperma menjadi kerdil dan hal ini yang memungkinkan berkurangnya tingkat motilitas tetapi tidak diketahui apakah sel sperma yang kerdil tersebut masih hidup [3].

\section{Daya Tetas Telur (Hatching Rate)}

Telur yang sudah dibuahi kemudian dipelihara dan diamati selama 40 jam sampai menetas didapatkan data daya tetas telur (hatching rate, HR) dari tiap perlakuan sebagaimana ditampilkan pada Tabel 10 dan Gambar 7.

Tabel 9. Hasil Sidik Ragam

\begin{tabular}{|c|c|c|c|c|c|c|}
\hline \multirow{2}{*}{ Sumber Keragaman } & \multicolumn{6}{|c|}{$\mathrm{F}$} \\
\hline & $\mathrm{Db}$ & JK & KT & Hit & F 5\% & F 1\% \\
\hline Perlakuan & 4 & 592,83 & 148,2 & $1,34^{\mathrm{ns}}$ & 3,48 & 5,99 \\
\hline Acak & 10 & 1103,63 & 110,36 & & & \\
\hline Total & 14 & 1696,46 & & & & \\
\hline
\end{tabular}

Keterangan: ${ }^{\text {ns }}$ tidak berbeda nyata 
Tabel 10. Daya Tetas Dari Telur yang Dibuahi dengan Sperma Terelektroporasi (\%)

\begin{tabular}{|c|c|c|c|c|c|}
\hline \multirow{2}{*}{ Perlakuan } & \multicolumn{3}{|c|}{ Ulangan } & \multirow{2}{*}{ Total } & \multirow{2}{*}{$\begin{array}{l}\text { Rata } \\
\text { rata }\end{array}$} \\
\hline & 1 & 2 & 3 & & \\
\hline $40 \mathrm{~V}$ & 42,8 & 50,55 & 21,03 & 114,38 & 38,13 \\
\hline $160 \mathrm{~V}$ & 30,63 & 35,79 & 30,63 & 97 & 32,35 \\
\hline $280 \mathrm{~V}$ & 31,73 & 6,27 & 50,55 & 88 & 29,52 \\
\hline $400 \mathrm{~V}$ & 17,34 & 34,69 & 19,93 & 71,96 & 23,99 \\
\hline \multirow[t]{2}{*}{$520 \mathrm{~V}$} & 37,69 & 23,62 & 15,12 & 76,43 & 25,48 \\
\hline & Total & & & 448,37 & \\
\hline Kontrol & 69 & 64,58 & 56,83 & 190,41 & 63,47 \\
\hline
\end{tabular}

Dari Tabel 10., diketahui bahwa perlakuan yang mempunyai nilai HR tertinggi yaitu pemberian tegangan $40 \mathrm{~V}$ dengan nilai rata-rata $38,13 \%$ hal ini menunjukkan bahwa nilai HR dipengaruhi oleh tingkat motilitas (Tabel 10 ) yang menunjukkan bahwa pada tegangan $40 \mathrm{~V}$ memiliki nilai motilitas tertinggi sehingga daya fertilisasinya juga tinggi. Keberhasilan dari suatu pembuahan telur oleh sperma sangat dipengaruhi oleh motilitas sperma, karena keadaan viabilitas yang panjang belum tentu dapat menghasilkan fertilisasi yang tinggi, karena pada keadaan ini spermatozoa sangat membutuhkan banyak energi untuk membuahi sel telur $[21,25]$.

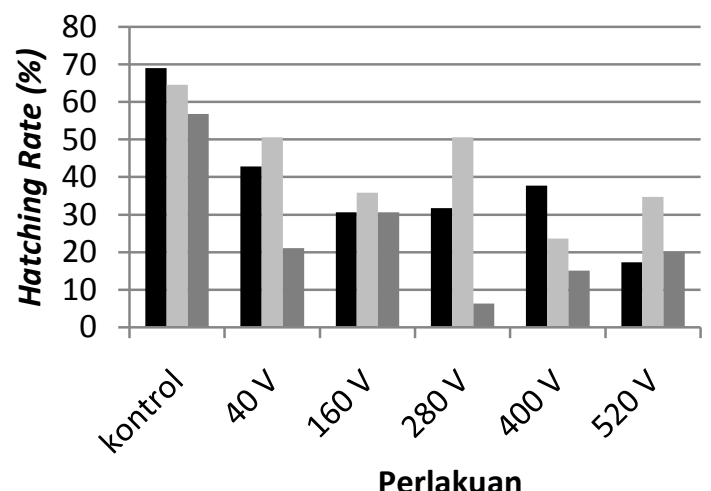

- ulangan 1 ulangan 2

Gambar 7. Diagram Daya Tetas Telur yang Dibuahi dengan Sperma Terelektroporasi

Dari grafik pada Gambar 7 dapat diketahui bahwa terdapat beberapa perlakuan yang memiliki nilai HR di bawah 20\%, hal ini disebabkan karena rendahnya daya fertilisasi sperma yang dipicu oleh terjadinya peningkatan suhu pada proses pemberian kejutan. Peningkatan suhu yang terjadi pada sperma dalam cuvet yang menyebabkan sperma mati seperti disampaikan Toelihere (1981) dalam Rustidja (2000), kemampuan hidup (viabilitas) spermatozoa sangat dipengaruhi oleh suhu dan secara umum akan hidup lebih lama dalam suhu rendah [16].

Tabel 11. Hasil Sidik Ragam Hatching Rate (HR)

\begin{tabular}{ccccccc}
\hline $\begin{array}{c}\text { Sumber } \\
\text { ragam }\end{array}$ & $\mathrm{db}$ & $\mathrm{JK}$ & $\mathrm{KT}$ & $\mathrm{F} \mathrm{Hit}$ & $5 \%$ & $\mathrm{~F} \mathrm{1 \%}$ \\
\hline Perlakuan & 4 & 385,1 & 96,28 & $0,50^{\mathrm{ns}}$ & 3,48 & 5,99 \\
Acak & 10 & 1909 & 190,90 & & & \\
Total & 14 & 2294,1 & & & & \\
\hline \multicolumn{7}{l}{ Keterangan: ${ }^{\mathrm{ns}}$ tidak berbeda nyata }
\end{tabular}

Perhitungan sidik ragam pada Tabel 11, menyatakan bahwa HR yang dibuahi dengan sperma yang diberi perlakuan kejutan listrik tidak berbeda nyata.

Motilitas dari sperma ikan merupakan parameter dari kelangsungan hidup sperma, disini terlihat akan menurun dengan semakin meningkatnya tegangan dan lama kejutan [13]. Tingkat survival dari embrio yang dibuahi dengan sperma yang dielektroporasi dan dengan sperma tanpa perlakuan tidak tampak perbedaan. Tsai et al (1995) mengungkapkan bahwa memang tidak begitu banyak perbedaan daya tetas telur antara yang dibuahi dengan sperma terelektroporasi dan sperma kontrol hanya selisih $4 \%$ lebih besar pada sperma kontrol [26].

Hal ini juga tidak terlepas dari metode kejutan yang dipakai yaitu metode square wave. Metode ini dapat menghasilkan tegangan yang besar sehingga efisiensi pemasukkan DNA asing lebih besar karena pembukaan pori relatif lebih besar, namun gelombangnya sangat pendek (pulse length) sehingga mencegah sel rusak dan dapat kembali seperti semula karena panas yang ditimbulkan relatif kecil [27].

\section{Hubungan Antar Motilitas dengan Viabilitas} Sperma

Dari Gambar 8., dapat diketahui bahwa motilitas sperma menurun dengan semakin meningkatnya tegangan yang diberikan, begitu juga dengan viabilitas sperma yang secara umum menunjukkan kecendrungan penurunan.

Selain itu dari gambar tersebut juga menunjukkan bahwa persentase viabilitas sperma lebih tinggi daripada persentase motilitas sperma karena sel sperma cenderung akan mengecil setelah dilakukan elektroporasi dan hal ini memungkinkan menurunnya tingkat motilitas sperma [3]. Selain itu sel sperma yang sudah diberi kejutan listrik mengalami pembukaan poripori secara sementara dan terjadi difusi molekul asing ke dalam sel [13]. Hal tersebut memungkinkan terjadinya pertukaran zat makanan sperma dengan cairan yang ada diluar 
sel sehingga menyebabkan penurunan motilitas sel sperma, namun viabilitas sperma tetap terjaga karena setelah pori-pori menutup maka sel sperma akan kembali seperti semula.

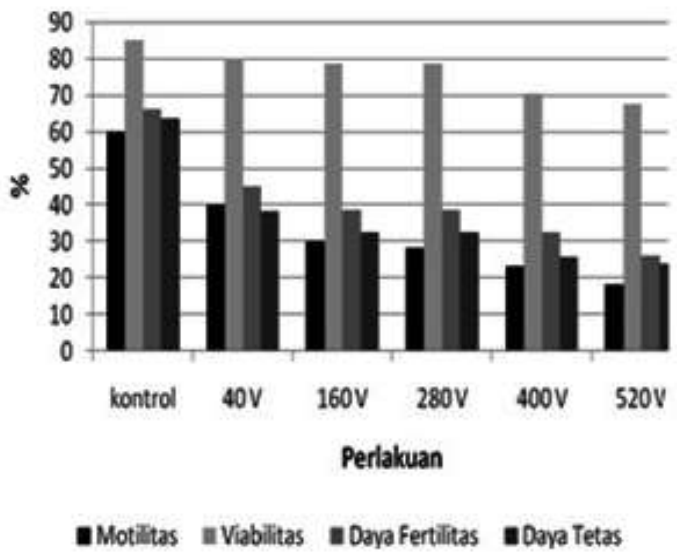

Gambar 8. Perbandingan Tiap Parameter dengan Tegangan Berbeda

\section{Motilitas Dengan Daya Fertilisasi Sperma}

Hubungan antara motilitas sperma terelektroporasi dengan daya fertilisasi sperma seperti ditampilkan pada Gambar 8 menunjukkan bahwa nilai motilitas berbanding lurus dengan nilai daya fertilisasi sperma, pada setiap tegangan. Keberhasilan pembuahan oleh sperma dipengaruhi oleh motilitas sperma karena ketika sel telur mengeluarkan zat chemoattractants dalam air maka sperma akan mengikuti sinyal tersebut [25]. Sehingga dari pernyataan tersebut, apabila sperma tidak memiliki tingkat motilitas yang tinggi maka nilai daya fertilisasinya cenderung rendah.

Daya fertilisasi sperma juga ditunjang dengan penambahan larutan pengencer Natrium fisiologis. Pemberian larutan fruktosa sebagai pengencer untuk spermatozoa ikan dimaksudkan untuk memberikan energi dan nutrisi untuk spermatozoa ikan agar dengan energi yang berupa ATP tersebut dapat meningkatkan atau memperpanjang waktu motilitas spermatozoa [21].

\section{Viabilitas Dengan Daya Fertilisasi Sperma}

Dari Diagram pada Gambar 8 menunjukkan bahwa tingkat viabilitas sperma tidak mempengaruhi daya fertilisasi sperma. Menurut Hidayaturrahmah (2007) bahwa keadaan viabilitas yang panjang belum tentu dapat menghasilkan fertilisasi yang tinggi karena untuk membuahi sel telur, spermatozoa memerlukan banyak energi [21].

Viabilitas sperma tetap tinggi karena metode pemberian kejutan yang digunakan yaitu metode square wave, sehingga kemungkinan kerusakan pada sel sperma lebih kecil. Chen et al (2009) menyatakan bahwa metode square wave dapat menghantarkan tegangan tinggi dalam gelombang yang pendek sehingga menimbulkan sedikit panas, sehingga transfer DNA dapat terjadi tanpa membunuh sel atau embrio [24].

Sperma dalam kondisi viabil (pergerakannya rendah) masih memungkinkan untuk melakukan pembuahan karena menurut Hidayaturrahmah (2007), kondisi motilitas sperma slow progressive mempunyai kemampuan spermatozoa untuk menembus lubang mikropil cukup lemah, pembuahan bisa saja terjadi apabila jarak antara spermatozoa dan sel telur sangat dekat. Sperma pada kondisi viabil, kemampuan spermatozoa untuk melakukan fertilisasi sangat kecil yaitu hanya sekitar 10\% [21].

\section{Daya fertilisasi Sperma Dengan Daya Tetas Telur}

Pada Gambar 8., menunjukkan bahwa jumlah telur yang menetas mengalami penurunan dari jumlah telur yang terbuahi, hal yang sama juga terjadi pada telur kontrol. Menurut Sin (2001), kelulushidupan embrio yang dibuahi dengan sperma yang dielektroporasi dan dengan sperma tanpa perlakuan tidak tampak perbedaan [13]. Ditambahkan oleh Tsai et al (1995) bahwa memang tidak begitu banyak perbedaan daya tetas telur antara yang dibuahi dengan sperma terelektroporasi dan sperma kontrol hanya selisih 4\% lebih besar pada sperma control [26].

\section{KESIMPULAN DAN SARAN \\ Kesimpulan}

Pemberian tegangan listrik berpengaruh nyata terhadap motilitas sperma, tetapi tidak berpengaruh terhadap viabilitas, daya fertilisasi sperma dan daya tetas telur ikan lele dumbo. Pemberian tegangan listrik dapat menurunkan tingkat motilitas sperma ikan lele dumbo (Clarias spp).

Saran

Elektroporasi pada sperma ikan lele dumbo (Clarias sp) sebagai media transfer gen sebaiknya dilakukan pada tegangan $40 \mathrm{Vcm}^{-1}$ dengan 1 kali kejutan dan lama kejutan $0.05 \mathrm{~ms}$.

\section{DAFTAR PUSTAKA}

1. Lavitrano, M., Marcho, B., Maria, G. C., Roberto, G., Stefano, M. and Alessia. 2006. Sperm Mediated Gene Transfer, Reprod. Fertility and Development 18. CSIRO Publishing. Victoria. 
2. Muller, F., Ivich, Z., Erdelyi, F., Papp, T., Varadi, L., Horvart, L and Maclean, N. 1992. Introducing Foreign Gene Into Fish Eggs With Electroporated Sperm as Carrier. Mol. Biol. Biotechnol. I : $276-281$.

3. Sin, F.Y.T., Mukherjee, U.K., McKenzie, J.C and Sin, I. L. 1995. Abalone Sperm-DNA Interaction. In: Proceedings of International Symposium On Biotecnology Applications In Aquaculture. National Taiwan University :9599.

4. Chen, T. T. 1995. Transgenic Fish: Ideal Models for Basic Research and Biotechnological Applications In: Proceedings Of International Symposium On Biotecnology Applications In Aquaculture. National Taiwan University :55-70.

5. Taghyr. 2008. Pengertian Hambatan, Arus, Tegangan dan Bunyi Hukum OHM http://taghyr.wordpress.com/2008/08/20/pe ngertian-hambatan-arus-tegangan-dan-bunyihukum-ohm/. Tanggal akses 20 Agustus 2008.

6. Symond, J. E., Walker S. P. and Sin, F. Y. T. 1994a. Elektroporation of Salmon Sperm With Plasmid DNA ; Evidence of Enchanned Sperm/ DNA Assosition. Aquaculture 199:313 - 327.

7. Samarsik, A., Warr, G and Chen, T. T. 2002. Production Transgenik Fish With Elevated Levels of Innet Devense Activity to Bacterial Pathogen. Mar. Biotech. 4:310 - 322.

8. Hackett, P. B. 1993. The Molecular Biology of Transgenic Fish. In Hocacha and Hommesen (eds) Biochemestry and Molecular Biology of Fishes. Elvsevier Publisher BV. 2:218 - 221

9. Weaver, J. C. 1995. Electroporation Theory: Concepts and Mechanisms. In: Nickoloff JA, editor. Electroporation Protocols for Microorganisms. Humana Press. Totowa.

10. Arie, Usni. 2008. Budidaya Ikan Mas (Cyprinus Carpio L.). http://solusiikanmas.blogspot.com /2008/04/sperma-ikan-mas.html. Tanggal akses 1 April 2008.

11. Sucipto, Adi. 2008. Petunjuk Teknis Gynogenesis pada Ikan Mas. http://nak sara.net/Aquaculture/Genetic/Page-3.html. Tanggal akses 27 Februari 2008.

12. Gilbert S.F. 2000. Developmental Biology. Sixth Edition. Sinauer Associates. Sunderland.

13. Sin, F.Y.T. 2001. Gene Transfer Technology for Salmon. In Recent Advances in Marine Biotechnology Vol 10, Molecular Genetics of Marine Organism. Milton, F., Rachakonda, N., (ed). Science Publisher. USA.
14. Harvey, B.J., Hoar, W.S. 1979. The Teory and Practice of Induced Breeding in Fish. Ont. IDRC-TS 21e. Ottawa.

15. Dacie, J.V and Lewis, S.M. 1984. Practical haematology. Churchill Livingstone. London.

16. Rustidja. 2000. Prospek Pembekuan Sperma. Fakultas Perikanan Universitas Brawijaya. Malang.

17. Toelihere, M.R. 1981. Inseminasi Buatan pada Ternak. Angkasa. Bandung.

18. Tabares, J., T. Ruiz, Lucy A and Martha 0. 2007. Effect of Some lons on Sperm Activation in Brycon henni (Eigenmann, 1913). Scielo. Acta biol Colomb. Vol. 12 no 1. Bogota

19. Mochida K, Kondo T, Matsubara T, Adachi S and Yamauchi K. 1999. A High Molecular Weight Glycoprotein in Seminal Plasma is a Sperm Immobilizing Factor in the Teleost Nile Tilapia, Oreochromis niloticus. Dev Growth Differ. 41:619627

20. Morosawa, M., Suzuki K. 1980. Osmolality and Potassium Ion; Their Role in Initation of Sperm Motility in Teleosts. Science, N.Y. 210:1145-1147

21. Hidayaturrahmah. 2007. Waktu Motilitas dan Viabilitas Spermatozoa Ikan Mas (Cyprinus carpio L.) Pada Beberapa Konsentrasi Larutan Fruktosa. Program Studi Biologi Fakultas MIPA Universitas Lambung Mangkurat. Kalsel. http://www.unlam.ac.id/bioscientiae. Tanggal akses 1 Januari 2007.

22. Sun, S.P., N.C. Venzon Jr., Fernanda R.O.C and David, M.E. 2004. Evaluation of Methods for DNA Delivery into Shrimp Zygotes of Panaeus (Litopenaeus) vannamei. Science direct. Aquaculture 243:19-26.

23. BIO-RAD. 2006. Gene Pulser Xcell Electroporation System. Instruction Manual. BIO-RAD.

24. Chen, T.T., M.J. Chen, Tzu-Ting Chiou dan J.K. Lu. 2009. Transfer of Foreign DNA into Aquatic Animals by Electroporation. In $\mathrm{H}$. Nakamura (ed.), Electroporation and Sonoporation in Developmental Biology. Springer :229-237

25. Cierezsko, A., K. Dabrowski., B. Piros., M. Kwasnik and J. Glogowski. 2001. Characterization of zebra mussel (Dreissena polymorpha) sperm motility: duration of movement, effects of cations, $\mathrm{pH}$ and gossypol. Kluwer Academic. Netherlands. Hydrobiologia. 452:225-232

26. Tsai, H. J., F.S. Tseng and I.C. Liao. 1995. Electroporation of sperm to introduce foreign DNA into the genome of Loach (Misgurnus 
anguillicaudatus). Can. J. Fish. Aquat. Sci. 52: 776-787

27. Huang, K.S., Lin, Y.C., Su, K.C., Chen, H.Y. 2007. An Electroporation Microchip System for Transfection of Zebrafish Embryos using Quantum Dots and GPF Genes for Evaluation. Biomed Microdevice 9:761-768 